\title{
PENGARUH STRES KERJA DAN MOTIVASI KERJA TERHADAP KEPUASAN KERJA PADA KARYAWAN BANK MANDIRI SYARIAH CABANG PADANG
}

\author{
Muhammad Ridho, Febsri Susanti \\ Sekolah Tinggi Ilmu Eknomi "KBP” \\ febsrisusanti@akbpstie.ac.id
}

\begin{abstract}
ABSTRAK
Dalam penelitian ini, peneliti meneliti memilih karyawan Bank Syariah mandiri cab. Padang yang mana merupakan salah satu bank syariah yang besar di kota padang adapun beberapa alasan peneliti adalah setiap hari kerja, Bank Mandiri Syariah belakang olo selalu melayani nasabah dalam jumlah yang tidak sedikit. Hal ini tentu menjadi tanggung jawab karyawan untuk senantiasa memberikan pelayanan maksimal terhadap para nasabah dalam setiap transaksi, selain dari tuntutan kerja dan banyak nya jumlah nasabah setiap hari penyebab stress karyawan Bank Mandiri Syariah tersubut adalah tuntutan target yang sangat tinggi dari Bank. Bentuk persamaan regresi dapat di tulis sebagai berikut $\mathrm{Y}=4,221-0,293 \mathrm{X} 1+1,129 \mathrm{X} 2$, nilai thitung untuk variabel stres kerja sebesar - 2,242 dengan signifikansi 0,028. Nilai Sig. variabel stres kerja sebesar 0,028 < 0,05 , Selanjutnya diketahui nilai thitung untuk variabel motivasi kerja sebesar 8,079 dengan signifikansi 0,000. Nilai Sig. variabel motivasi kerja sebesar 0,000 $<0,05$.

Kata Kunci : Stres Kerja, Motivasi Kerja, dan Kepuasan Kerja
\end{abstract}

\section{Latar Belakang}

Sumber daya manusia merupakan aset yang penting penting dalam sebuah organisasi bisnis atau sebuah perusahaan, karena perannya sebagai subyek pelaksana kebijakan dan kegiatan operasional perusahaan.Sumber daya yang dimiliki oleh perusahaan seperti modal, metode dan mesin tidak bisa memberikan hasil yang optimal apabila tidak didukung oleh sumber daya manusia yang mempunyai kinerja yang optimal. Untuk mendapatkan hasil kinerja yang optimal sumber daya manusia harus dikelola dan di manage dengan sebaik mungkin, sehingga sumber daya manusia dalam sebuah perusahaan merasa nyaman dalam menjalankan tugasnya dan mendapatkan hasil yang maksimal. Simamora (2006) menyatakan bahwa manajemen sumber daya manusia (human resources management) adalah pendayagunaan, pengembangan, penilaian, pemberian balas jasa, dan pengelolaan individu anggota organisasi atau kelompok karyawan.
Untuk dapat meraih prestasi sesuai dengan cita-cita dan harapan perusahaan maka seorang pemimpin dituntut untuk memiliki sebuah kebijakan maupun program yang ditujukan kepada para karyawannya agar setiap individu karyawan mendapatkan tingkat kepuasan kerja yang tinggi sehingga dapat berkontribusi secara optimal kepada perusahaan.karyawan kepada perusahan. Harapannya, hal ini dapat meningkatkan kepuasan kerja dan menumbuhkan semangat kerja pada diri karyawan tersebut.

Karyawan adalah salah satu sumber daya penting dalam kehidupan perusahaan. Meskipun memiliki sarana dan prasarana yang baik, namun jika perusahaan tidak memiliki karyawan yang memiliki kompetensi maka akan sulit bagi perusahaan untuk bersaing dengan pesaing-pesaing potensial.

Peran karyawan dalam sebuah organisasi perusahaan merupakan faktor yang sangat vital untuk mencapai dan 
menjalankan fungsi serta tujuan dari perusahaan.Karyawan menjadi perencana, pelaksana, dan pengendali yang selalu berperan aktif dalam mewujudkan tujuan organisasi atau industri. Karyawan sebagai penunjang tercapainya tujuan, akan tetapi karyawan juga memiliki pikiran, perasaan, dan keinginan yang memengaruhi sikapsikapnya terhadap pekerjaannya. Sikap ini akan menjadi dan menentukan prestasi kerja, dedikasi, dan kecintaannya dalam pekerjaan yang di bebankan kepadanya. Sikap-sikap karyawan ini dikenal sebagai kepuasan kerja, stress, dan frustasi yang di timbulkan oleh pekerjaan, peralatan, lingkungan, kebutuhan dan sebagainnya.

Stress yang tinggi dan ditambah dengan motivasi yang rendah akan menimbulkan ketidakpuasan.

Ketidakpuasan karyawan dapat dinyatakan dalam sejumlah cara (Robbins dan Judge, 2008), antara lain; keluar (exit), yaitu perilaku yang ditujukan untuk meninggalkan organisasi, termasuk mencari posisi baru dan mengundurkan diri, aspirasi (voice), yaitu secara aktif dan konstruktif berusaha memperbaiki kondisi, termasuk menyarankan perbaikan, mendiskusikan permasalahan dengan atasan, dan beberapa bentuk aktivitas serikat kerja, kesetiaan (loyalty), yaitu secara pasif tetapi optimistis menunggu membaiknya kondisi, termasuk membela organisasi ketika berhadapan dengan kecaman eksternal dan mempercayai organisasi dan manajemennya untuk "melakukan hal yang benar", dan pengabaian (neglect), yaitu secara pasif membiarkan kondisi menjadi lebih buruk, termasuk ketidakhadiran atau keterlambatan yang terus-menerus, menurunnya kinerja karyawan, dan meningkatnya tingkat kesalahan

Pada umumnya stress dipandang sebagai kondisi negatif. Namun stress dalam tingkatan tertentu, dapat memicu kinerja karyawan menjadi lebih baik Karena stress muncul akibat dari tekanantekanan baik dari atasan, maupun persaingan dilingkungan kerja. Ini dapat terjadi karena stress dalam tingkatan tertentu dapat memicu karyawan untuk menciptakan gagasan- gagasan yang inovatif untuk menyelesaikan masalah dan pekerjaan sehingga stress menjadi suatu keadaan yang konstuktif. Misalnya seseorang mempunyai target tertentu dalam pekerjaannya yang mengharuskannya untuk mengerahkan lebih banyak tenaga maka orang tersebut akan mengalami stress hingga target pekerjaannya tercapai dan mencapai kepuasan kerja, dan juga tingkat stress yang dialami akan menurun. Namun jika target tersebut terlalu tinggi dan tidak dapat dicapai atau perlu usaha yang sangat keras untuk menyelesaikannya, maka seseorang akan mengalami tingkat stress yang berlebih dan pada akhirnya akan berdampak pada penurunan kepuasan kerja.

\section{PerumusanMasalah}

Berdasarkan problem statement dan research problem tersebut di atas, maka pertanyaan penelitian (research question) dalam penelitian ini dapat dirumuskan sebagai berikut:

1. Bagaimanakah pengaruh stress kerja terhadap kepuasan kerja karyawan Bank Syariah Mandiri?

2. Bagaimanakah pengaruh Motivasi kerja terhadap kepuasan karyawan Bank Syariah Mandiri?

\section{Tujuan Penelitian}

Tujuan penelitian ini adalah

1. Untuk menganalisis pengaruh Stress Kerja terhadap Kepuasan Kerja karyawan Bank Syariah Mandiri.

2. Untuk menganalisis pengaruh Motivasi Kerja terhadap Kepuasan Kerja karyawan Bank Syariah Mandiri.

\section{Pengertian Kepuasan Kerja}

Kepuasan kerja (job satisfaction) adalah suatu sikap yang dimiliki pekerja mengenai pekerjaan mereka.Hal ini dihasilkan dari persepsi mereka mengenai pekerjaan (Ivancevich, John M., dkk; 2005). Menurut Robbins, Stephen P., dan Timothy A. Judge (2007) kepuasan kerja 
dapat didefinisikan sebagai perasaan positif tentang pekerjaan seseorang yang merupakan hasil dari evaluasi karakteristik-karakteristiknya.

Kepuasan kerja merupakan seperangkat perasaan karyawan tentang menyenangkan atau tidaknya pekerjaan mereka, yang menunjukkan kesesuaian antara harapan kerjanya dengan manfaat yang ia terima dalam perusahaan (Luthans, Fred, 2006). Kreitner, Robert dan Angelo Kinicki (2000) mendefinisikan kepuasan kerja adalah suatu efektivitas atau respon emosional terhadap berbagai aspek pekerjaan.

\section{Pengertian Stress Kerja}

Stres adalah kondisi dinamis di mana seorang individu dihadapkan dengan kesempatan, permintaan, atau sumber daya yang terkait dengan apa keinginan individu dan yang hasilnya dipandang untuk menjadi tidak pasti dan penting. (Robbin, Stephen.Dan Judge, Timothy A.; 2007). Kreitner, Robert. Dan Kinicki, Angelo (2000) mendefinisikan stress sebagai suatu respon yang adaktif, dihubungkan oleh karakteristik dan atau proses psikologis individu, yangmerupakan suatu konsekuensi dari setiap tindakan eksternal, situasi, atau peristiwa yang menempatkan tuntutan psikologis dan atau fisik khusus pada seseorang. Definisi stress Ivancevich, John M., dkk (2005) hampir sama dengan menyatakan stress sebagai suatu respon adaktif, dimoderasi oleh perbedaan individu, yang merupakan konsekuensi dari setiap tindakan, stuasi, atau peristiwa dan yang menempatkan tuntutan khusus terhadap seseorang.

\section{Pengertian Motivasi}

McShane, Steven, dan Von Gillow, Mary Ann (2010) mendefinisikan motivasi sebagai " the forces within a person that affect the direction, intensity, and persistence of voluntary behavior ", yang kurang lebih berartimenggambarkan motivasi sebagai kekuatan dalam diri seseorang yang mempengaruhi arah, intensitas, dan ketekunan perilaku secara sukarela. Robbins, Stephen P. (1996) mendefiniskan motivasi sebagai kesediaan untuk mengeluarkan tingkat upaya yang tinggi ke arah tujuan organisasi, yang dikondisikan oleh kemampuan upaya itu untuk memenuhi suatu kebutuhan individual. Munandar (2001) mendefinisikan motivasi sebagai proses dimana kebutuhan-kebutuhan mendorong seseorang untuk melakukan serangkaian pekerjaan yang mengarah ke tercapainya tujan tertentu.

\section{Jenis Penelitian}

Penelitian ini tergolong penelitian deksriptif. Berdasarkan masalah yang akan diteliti pada penelitian ini maka jenis penelitian ini adalah penelitian kuantitatif dan penelitian kualitatif. Penelitian kualitatif memberikan gambaran respon sampel penelitian pengaruh Stress Kerja dan Motivasi Kerja terhadap Kepuasan Kerja karyawan Bank Syari'ah Mandiri cab Padang. Penelitian kuantitatif data yang berbentuk angka yaitu untuk menganalisa penelitian pengaruh Stress Kerja dan Motivasi Kerja terhadap Kepuasan Kerja karyawan Bank Syari'ah Mandiri cab. Padang

\section{Uji Validitas}

Sebelum dilakukan pengujian hipotesis, maka intrumen masing - masing variabel penelitian dilakukan uji validitas. Uji validitas mengukur sejauh mana pernyataan - pernyataan dalam koesioner dapat mengukur apa yang sebenarnya ingin diukur. Jika hasil Corrected ItemTotal Correlation > 0,30 dianggap signifikan artinya hasil uji validitas dari semua item pernyataan dapat dikatakan valid.

\section{Variabel Stres Kerja}

Dari data yang diperoleh berdasarkan jawaban responden maka dapat dilihat untuk variabel stres kerja nilai validitasnya seperti yang dikemukanan pada tabel 1 . 
Tabel 1

Hasil Uji Variabel Stres Kerja Item-Total Statistics

\begin{tabular}{|l|r|r|}
\hline & $\begin{array}{c}\text { Corrected Item- } \\
\text { Total Correlation }\end{array}$ & Keterangan \\
\hline P1 & .510 & Valid \\
\hline P2 & .679 & Valid \\
\hline P3 & .636 & Valid \\
\hline P4 & .612 & Valid \\
\hline P5 & .633 & Valid \\
\hline P6 & .647 & Valid \\
\hline
\end{tabular}

Sumber : SPSS 16

Dari tabel tersebut dapat diambil kesimpulan bahwa pernyataan variabel stres kerja dapat dikatakan valid karena Corrected Item-Total Correlation melebihi 0,3 sehingga dapat dilanjutkan untuk penelitian lebih lanjut.

\section{Variabel Motivasi Kerja}

Dari data yang diperoleh berdasarkan jawaban responden maka dapat dilihat untuk variabel motivasi kerja nilai validitasnya seperti yang dikemukanan pada tabel 2 .

Tabel 2

Hasil Uji Variabel Motivasi Kerja
\begin{tabular}{|l|r|r|}
\multicolumn{3}{|c|}{ Item-Total Statistics } \\
\hline & $\begin{array}{c}\text { Corrected Item-Total } \\
\text { Correlation }\end{array}$ & Keterangan \\
\hline P1 & .623 & Valid \\
\hline P2 & .646 & Valid \\
\hline P3 & .596 & Valid \\
\hline P4 & .647 & Valid \\
\hline P5 & .664 & Valid \\
\hline P6 & .393 & Valid \\
\hline
\end{tabular}

Sumber : SPSS 16

Dari tabel tersebut dapat diambil kesimpulan bahwa pernyataan variabel motivasi kerja dapat dikatakan valid karena Corrected Item-Total Correlation melebihi 0,3 sehingga dapat dilanjutkan untuk penelitian lebih lanjut.

\section{Variabel kepuasan Kerja}

Dari data yang diperoleh berdasarkan jawaban responden maka dapat dilihat untuk variabel kepuasan kerja nilai validitasnya seperti yang dikemukanan pada tabel 3 .
Tabel 3

Hasil Uji Variabel Kepuasan Kerja Item-Total Statistics

\begin{tabular}{|l|r|r|}
\hline & $\begin{array}{c}\text { Corrected Item- } \\
\text { Total Correlation }\end{array}$ & Keterangan \\
\hline P1 & .595 & Valid \\
\hline P2 & .334 & Valid \\
\hline P3 & .508 & Valid \\
\hline P4 & .600 & Valid \\
\hline P5 & .648 & Valid \\
\hline P6 & .615 & Valid \\
\hline
\end{tabular}

Sumber : SPSS 16

Dari tabel tersebut dapat diambil kesimpulan bahwa pernyataan variabel kepuasan kerja dapat dikatakan valid karena Corrected Item-Total Correlation melebihi 0,3 sehingga dapat dilanjutkan untuk penelitian lebih lanjut.

\section{Uji Reliabilitas}

Setelah melakukan uji valaditas kemudian dilanjutkan dengan uji realibilitas. Hasil olahan data tersebut dikemukan pada tabel 4.

\section{Tabel 4}

\section{Hasil Uji Reliabilitas}

\begin{tabular}{|l|l|c|c|}
\hline No & \multicolumn{1}{|c|}{ Variabel } & $\begin{array}{c}\text { Cronbach's } \\
\text { Alpha }\end{array}$ & Reliabilitas \\
\hline 1. & Stres Kerja & 0,840 & Reliabel \\
\hline 2. & Motivasi Kerja & 0,824 & Reliabel \\
\hline 3. & Kepuasann Kerja & 0,789 & Reliabel \\
\hline
\end{tabular}

Sumber : Data diolah SPSS 16

Dari tabel 4 dapat diambil kesimpulan bahwa dari uji reliabilitas dihasilkan nilai Cronbach's Alpha untuk variabel penelitian yaitu stres kerja, Motivasi Kerja ,dan kepuasan kerja lebih dari 0,60 yang memberikan hasil bahwa variabel yang diteliti memenuhi syarat konsistensi ( reliabilitas ). Jadi item - item pernyataan untuk variabel penelitian dapat dipakai sebagai alat ukur dalam penelitian.

\section{Analisis Deskripsi}

Dari pernyataan pada kusioner yang telah diajukan kepada para responden, Berbagai tanggapan dari responden tersebut dapat disajikan sebagai berikut :

\section{Stres Kerja}

Berdasarkan data yang diperoleh dari jawaban kusioner penelitian yang telah 
dibagikan oleh peneliti, diperoleh deskripsi data mengenai Stres kerja secara umum sebagai berikut.

\section{Tabel 5}

Distribusi Frekuensi Skor Jawaban Variabel Stress Kerja pernyataan yang termasuk kriteria sangat baik, hal ini harus dilakukan perbaikan pada pernyatan no 2 karena nilai TCR nya $74,47 \%$ terendah dari 6 pernyataan stres kerja. Hasil rata - rata TCR $77,45 \%$, secara keseluruhan stres dikategorikan

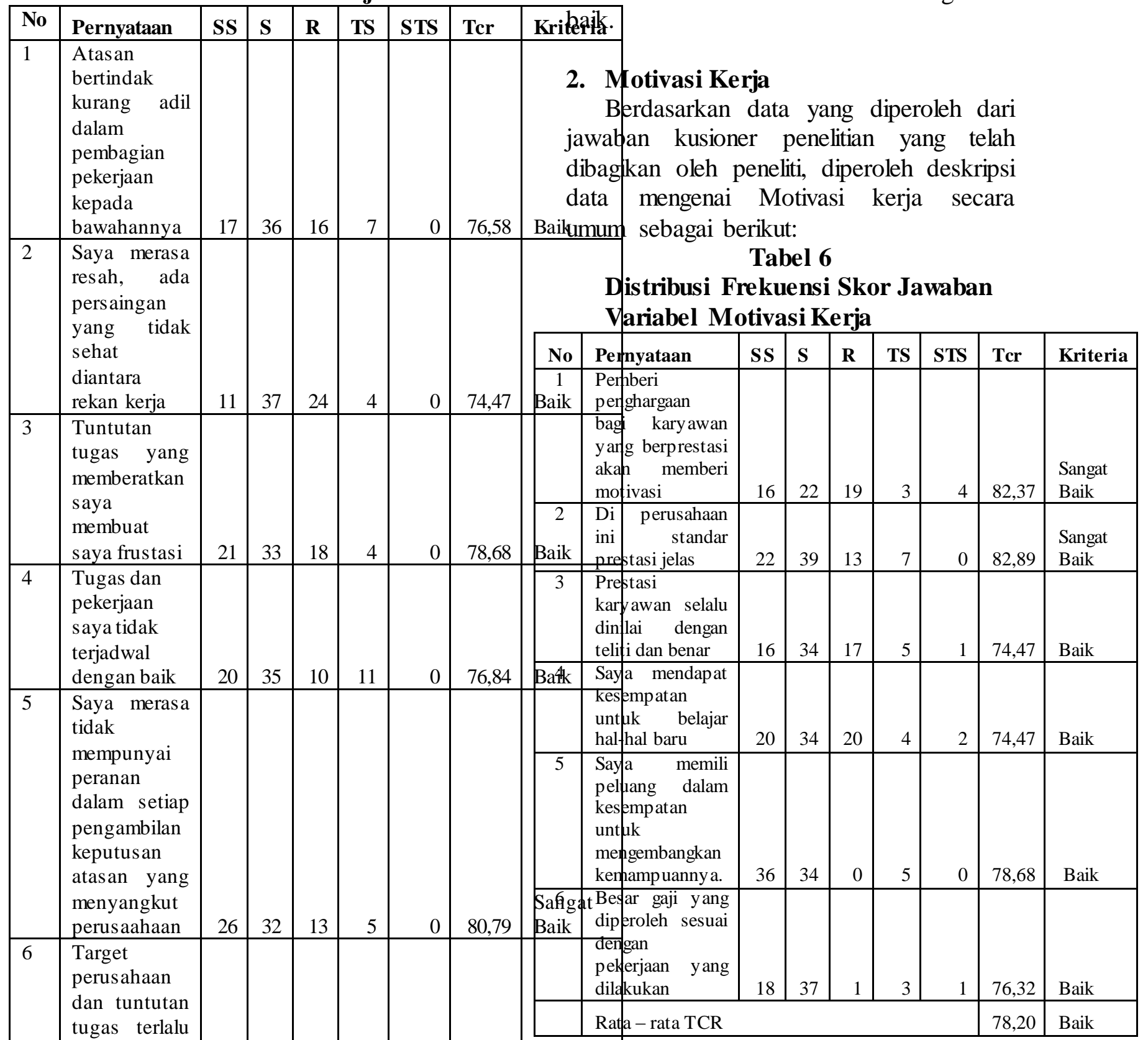

Sumber : Data Primer yang diolah,

Dari tabel diatas untuk pernyataan sehingga memberatkan tugas-tugas saya \begin{tabular}{l|l|l|l}
19 & 33 & 20 & 3
\end{tabular}

Rata - rata TCR

Sumber : Data Primer yang diolah,

Dari tabel diatas untuk pernyataan stres kerja terdapat 5 butir pernyataan yang termasuk kriteria baik dan 1 butir motivasi kerja terdapat 4 butir pernyataan aik yang termasuk kriteria baik dan 2 butir pernyataan yang termasuk kriteria sangat baik, hal ini harus dilakukan perbaikan pada pernyatan no 3 dan 4 karena nilai TCR nya $74,47 \%$ terendah dari 6 pernyataan motivasi kerja. Hasil rata - rata 
TCR 78,20\%, secara keseluruhan motivasi dikategorikan baik.

\section{Kepuasan Kerja}

Berdasarkan data yang diperoleh dari jawaban kusioner penelitian yang telah dibagikan oleh peneliti, diperoleh deskripsi data mengenai kepuasan kerja secara umum sebagai berikut

\section{Tabel 7}

Distribusi Frekuensi Skor Jawaban Variabel Kepuasan Kerja

\begin{tabular}{|c|c|c|c|c|c|c|c|c|}
\hline No & Pernyataan & SS & $\mathbf{S}$ & $\mathbf{R}$ & TS & STS & Tcr & $\mathbf{K}$ \\
\hline 1 & $\begin{array}{l}\text { Saya } \\
\text { ditempatkan } \\
\text { sesuai dengan } \\
\text { keahlian saya. }\end{array}$ & 20 & 30 & 5 & 9 & 3 & 76,32 & $\mathrm{~B}$ \\
\hline 2 & $\begin{array}{l}\text { Atasan dalam } \\
\text { menegakan } \\
\text { disiplin sangat } \\
\text { tegas }\end{array}$ & 33 & 35 & 8 & 5 & 0 & 86,84 & $\begin{array}{l}\mathrm{Sa} \\
\mathrm{B}\end{array}$ \\
\hline 3 & $\begin{array}{l}\text { Hubungan } \\
\text { dengan rekan } \\
\text { sekerja berjalan } \\
\text { dengan baik }\end{array}$ & 30 & 33 & 9 & 2 & 0 & 87,37 & B \\
\hline 4 & $\begin{array}{l}\text { Tidak ada } \\
\text { kesempatan } \\
\text { untuk } \\
\text { mengembangkan } \\
\text { karir }\end{array}$ & 25 & 35 & 14 & 2 & 0 & 83,16 & B \\
\hline 5 & $\begin{array}{lr}\text { Gaji dan } & \text { jenis } \\
\text { tunjangan } & \text { yang } \\
\text { diterima } & \text { sudah } \\
\text { sesuai } & \\
\end{array}$ & 30 & 43 & 5 & 6 & 0 & 82,89 & \\
\hline 6 & $\begin{array}{lr}\text { Fasilitas } & \text { yang } \\
\text { disediakan } & \text { oleh } \\
\text { perusahaan } & \\
\text { lengkap } & \text { dan } \\
\text { layak pakai. } & \end{array}$ & 24 & 28 & 7 & 5 & 0 & 72,63 & \\
\hline & & & & & & & 81.53 & \\
\hline
\end{tabular}

Sumber : Data Primer yang diolah, 2017(

Lampiran 3)

Dari tabel diatas untuk pernyataan kepuasan kerja terdapat 2 butir pernyataan yang termasuk kriteria baik dan 4 butir pernyataan yang termasuk kriteria sangat baik, hal ini harus dilakukan perbaikan pada pernyatan no 6 karena nilai TCR nya $72,63 \%$ terendah dari 6 pernyataan kepuasan kerja. Hasil rata - rata TCR $81,53 \%$, secara keseluruhan kepuasan kerja dikategorikan sangat baik.

\subsubsection{Uji Normalitas}

Uji Normalitas dilakukan untuk menguji apakah dalam sebuah model regresi variabel independen dan variabel dependen memiliki ditribusi normal atau tidak. Data dikatakan berdistribusi normal apabila Asymp Sig ( 2-tailed) lebih besar dari level of significant yang dipakai yaitu 0,05 . Hasil penelitian menujukan nilai signifikansi sebesar 0,721 ( 0,721>0,05). Hal ini berarti model regresi berdistribusi normal. Ini dapat dilihat pada tabel 4.9.

Tabel 8

Hasil Uji Normalitas

One-Sample Kolmogorov-Smirnov Test

\begin{tabular}{|l|l}
\hline & Unstandardized \\
\hline
\end{tabular}

Kri $\quad$ Residual

\begin{tabular}{|l|r|}
\hline$N$ & 76 \\
\hline
\end{tabular}

$\begin{array}{lll}\text { Normal Parameters }^{\mathrm{a}} \quad \text { Mean } & .0000000\end{array}$

Absolute

Positive a. Test distribution is Normal.

(Lampiran 4)

Sumber : Data diolah SPSS 16

\subsubsection{Analisa Regresi Berganda}

Analisis regresi berganda Baikfigunakan untuk mengetahui seberapa besar pengaruh variabel bebas dalam penelitian ini memiliki pengaruh terhadap variabel terikatnya. Perhitungan analisis Baildata dalam penelitian ini menggunakan Sangeteng lahan data dengan SPSS 16. Nilai perhitungan adalah seperti pada tabel

\section{berikut ini.}

Tabel 4.10

Hasil Uji Regresi Linear Berganda

\begin{tabular}{|c|c|c|c|c|c|}
\hline \multirow[b]{2}{*}{ Model } & \multicolumn{2}{|c|}{$\begin{array}{l}\text { Unstandardized } \\
\text { Coefficients }\end{array}$} & \multirow{2}{*}{$\begin{array}{c}\begin{array}{c}\text { Standardized } \\
\text { Coefficients }\end{array} \\
\text { Beta } \\
\end{array}$} & \multirow[b]{2}{*}{$t$} & \multirow[b]{2}{*}{ Sig. } \\
\hline & B & Std. Error & & & \\
\hline $\begin{array}{ll}1 & \text { (Cons } \\
& \text { tant) }\end{array}$ & 4.221 & 1.073 & & 3.934 & .000 \\
\hline $\mathrm{X} 1$ & -.293 & .131 & -.339 & -2.242 & .028 \\
\hline X2 & 1.129 & .140 & 1.221 & 8.079 & .000 \\
\hline
\end{tabular}


Sumber : Data diolah SPSS 16 ( Lampiran 4)

Bentuk persamaan regresi dapat di tulis sebagai berikut :

$\mathrm{Y}=4,221-0,293 \mathrm{X} 1+1,129 \mathrm{X} 2$

Hasil persamaan regresi berganda tersebut di atas memberikan pengertian bahwa :

1. Nilai constant sebesar 4,221 artinya jika variabel yang di teliti, dalam hal ini stres kerja dan motivasi kerja nilainya nol, maka kepuasan kerja tetap bernilai 4,221.

2. Nilai koefisien regresi stres kerja terhadap Kepuasan kerja - 0,293 yang berarti apabila stres kerja berkurang sebesar satu satuan dalam jawaban responden, maka akan menambah Kepuasan kerja sebesar satu satuan dengan asumsi faktor-faktor lain di anggap tetap (citeris paribus).

3. Nilai koefisien regresi motivasi kerja terhadap kepuasan kerja 1,129 yang berarti apabila motivasi kerja bertambah sebesar satu satuan dalam jawaban responden, maka akan menambah kepuasan kerja sebesar satu satuan dengan asumsi faktor-faktor lain di anggap tetap (citeris paribus).

\section{Hipotesis}

Uji F

Pengujian ini dilakukan untuk mengetahui apakah semua variabel independen secara bersama-sama (simultan) dapat mempengaruhi terhadap variabel dependen dari suatu persamaan regresi yang di dasarkan pada nilai probabilitas $a=0,05$.

\section{Tabel 10}

Uji F ( Simultan )

ANOVA $^{\circ}$

\begin{tabular}{|c|c|c|c|c|c|}
\hline Model & $\begin{array}{l}\text { Sum of } \\
\text { Squares }\end{array}$ & $d f$ & $\begin{array}{l}\text { Mean } \\
\text { Square }\end{array}$ & $F$ & Sig. \\
\hline $\begin{array}{l}1 \text { Regres } \\
\text { sion }\end{array}$ & 770.388 & 2 & $\begin{array}{r}385.19 \\
4\end{array}$ & $\begin{array}{r}169.6 \\
28\end{array}$ & .000 \\
\hline $\begin{array}{l}\text { Residu } \\
\text { al }\end{array}$ & 165.770 & 73 & 2.271 & & \\
\hline Total & 936.158 & 75 & & & \\
\hline
\end{tabular}

a. Predictors:

(Constant), X2, X1

b. Dependent Variable:

Y
Sumber : Data diolah SPSS 16 (Lampiran 4)

Nilai F hitung sebesar 169,628 yang signifikan $0.000^{\mathrm{a}}$. Karena sig $<0,05$ ini berarti rumusan hipotesis yang menyatakan bahwa stres kerja dan motivasi kerja berpengaruh secara simultan terhadap kepuasan kerja.

Uji Koefisien Determinasi ( $\mathbf{R}^{2}$ )

Hasil uji Koefisien Determinasi (

$R^{2}$ ) dalam penelitian ini dapat dilihat pada tabel berikut :

Tabel 9

Uji Koefisien Determinasi ( $\mathbf{R}^{2}$ )

\begin{tabular}{|l|c|r|r|r|}
\hline Model & $\mathrm{R}$ & R Square & $\begin{array}{c}\text { Adjusted R } \\
\text { Square }\end{array}$ & $\begin{array}{r}\text { Std. Error of } \\
\text { the Estimate }\end{array}$ \\
\hline 1 & $.907^{\mathrm{a}}$ & .823 & .818 & 1.507 \\
\hline
\end{tabular}

Sumber : Data diolah SPSS 16 ( Lampiran 4)

Pada tabel di atas di peroleh nilai adjusted $\mathrm{R}$ square adalah 0,818 artinya sebesar $81,8 \%$ variabel stres kerja dan motivasi kerja mampu menjelaskan terhadap Keputusan pembelian dan sisanya $18,2 \%$ dipengaruhi oleh faktor lain yang tidak diteliti.

\section{Uji T (Parsial)}

Pengujian ini bertujuan untuk mengetahui hubungan signifikan dari masing-masing variabel independen dan terhadap variabel dependen. Uji $t$ dilakukan untuk memeriksa lebih lanjut manakah diantara kedua variabel independen tersebut signifikan atau tidak terhadap kepuasan kerja yang dikemukakan pada tabel 4.10 di atas. Dari tabel 4.10 diketahui diperoleh nilai thitung untuk variabel stres kerja sebesar - 2,242 dengan signifikansi 0,028 . Nilai Sig. variabel stres kerja sebesar $0,028<0,05$ maka H1 ditolak, berarti terdapat pengaruh negatif dan signifikan antara variabel stres kerja terhadap kepuasan kerja pegawai di Bank Mandiri Syariah Cabang Padang.

Selanjutnya diketahui nilai thitung untuk variabel motivasi kerja sebesar 8,079 dengan signifikansi 0,000 . Nilai Sig. variabel motivasi kerja sebesar 0,000 
$<0,05$ maka H1 diterima, berarti terdapat pengaruh positif dan signifikan antara variabel motivasi kerja terhadap kepuasan kerja pegawai di Bank Mandiri Syariah Cabang Padang.

\section{Pembahasan}

\section{Pengaruh Stres Kerja Terhadap Kepuasan Kerja}

Berdasarkan hasil penelitian yang diperoleh setelah dilakukan pengujian terhadap 76 orang responden yang merupakan karyawan Bank Mandiri Cabang Padang maka nilai koefisien regresi stres kerja terhadap kepuasan kerja - 0,293 yang berarti apabila stres kerja berkurang maka kepuasan kerja akan bertambah dan dilihat juga hasil nilai thitung variabel stres kerja berpengaruh negatif dan signifikan terhadap kepuasan kerja pada karyawan Bank Mandiri Cabang Padang karena memiliki nilai thitung untuk variabel stres kerja sebesar 2,242 dengan nilai signifikansi 0,028. Artinya tidak ada hubungan antara stres kerja terhadap kepuasan kerja. Ini berarti bahwa stres kerja yang dialami oleh karyawan dapat mempengaruhi apa yang mereka rasakan, baik itu menyangkut pekerjaan maupun hasil yang mereka terima. Hasil analisis tersebut mengkonfirmasi teori ERG (Existence, Relatedness, Growth) dalam Robbins (2001) yang menyatakan bahwa semakin sulit memuaskan kebutuhan yang tingkatannya lebih tinggi, maka semakin besar pula keinginan memuaskan kebutuhan yang mendasar. Konsep stres kerja sesuai dengan teori yaitu seorang karyawan yang selalu berusaha untuk mencapai target dalam pekerjaannya dan akhirnya akan mempengaruhi kepuasan kerja dari karyawan tersebut.

Hasil analisis ini sejalan dengan penelitian yang dilakukan sebelumnya oleh I Gede putro wibowo ( 2014 ) dari Universitas Udayana Bali dan Mansoor et al. (2011) bahwa stres berhubungan negatif dan signifikan dengan kepuasan kerja karyawan yang memperkuat pentingnya kepuasan kerja karyawan yang sangat penting untuk keberhasilan perusahaan di era saat ini. Kurangnya kepuasan bisa menjadi sumber stres, sementara kepuasan yang tinggi dapat meringankan efek stres, itu berarti bahwa stres dan kepuasan kerja saling terkait (Bhatti et al, 2011).

\section{Pengaruh Motivasi Kerja Terhadap Kepuasan Kerja}

Berdasarkan hasil penelitian yang diperoleh setelah dilakukan pengujian terhadap 76 orang responden yang merupakan karyawan Bank Mandiri Cabang Padang maka nilai koefisien regresi motivasi kerja terhadap kepuasan kerja 1,129 yang berarti apabila motivasi kerja bertambah maka kepuasan kerja akan bertambah dan dilihat juga hasil nilai thitung variabel motivasi kerja berpengaruh positif dan signifikan terhadap kepuasan kerja pada karyawan Bank Mandiri Cabang Padang karena memiliki nilai thitung untuk variabel motivasi kerja sebesar 8,079 dengan nilai signifikansi 0,000 . Artinya adanya pengaruh antara motivasi kerja terhadap kepuasan kerja, hal ini menunjukkan bahwa adanya pemenuhan kebutuhan, pemenuhuhan berhubungan dan pemenuhan pertumbuhan yang akan memotivasi karyawan untuk bekerja, sehingga dapat tercapai kepuasan kerja karyawan. kepuasan kerja karyawan dapat dilihat dari segi kualitas kerja, kuantitas kerja dan ketepatan waktu dalam melaksankan semua pekerjaan yang diberikan atau dibebankan oleh perusahaan.

Penelitian ini mengembangkan teori dari Robbins (1999:50) mengidenfikasikan motivasi merupakan kesediaan untuk melaksanakan upaya tinggi untuk mencapai tujuan-tujuan keorganisasian, yang dikondisikan oleh kemampuan upaya, untuk memenuhi kebutuhan individu tertentu. Untuk mengembangkan sikap-sikap positif tersebut kepada pegawai, sebaiknya pimpinan harus terus memotivasi para pegawainya agar kepuasan kerja pegawainya menjadi tinggi, 
mengingat kepuasan kerja merupakan bagian dari kepuasan hidup yang bergantung pada tindakan mana individu menemukan saluran-saluran yang memadai untuk mewujudkan kemampuan, minat, ciri pribadi nilai-nilainya. Hal ini sesuai dengan penelitian yang pernah dilakukan oleh Yusmiati Saimah dengan judul "Pengaruh Motivasi Terhadap Kepuasan Kerja" pada dinas perhubungan Kabupaten Musi Rawas (2003 : 21). Gouzaly (2000 : 257), dalam bukunya "Manajemen Sumber Daya Manusia" mengelompokkan faktor-faktor motivasi kedalam kedalam dua kelompok yang dapat menimbulkan kepuasan kerja yaitu, faktor external dan faktor internal. Penelitian ini sejalan dengan penelitian Anwar Prabu (2005) dari Universitas Sriwijaya dan Awang Mada Kurnia, Bambang Swasto Sunuharyo, Hamidah Nayati Utami (2006) dari Fakultas Ilmu Administrasi Universitas Brawijaya yang menyatakan adanya pengaruh positif dan signifikan antara motivasi dan kepuasan kerja.

\section{Kesimpulan}

Berdasarkan uraian dan hasil analisis pada bab - bab sebelumnya mengenai Mengetahui Pengaruh Stres Kerja dan Motivasi kerja terhadap Kepuasan Kerja pada Karyawan Bank Mandiri Syariah Cabang Padang dapat diambil kesimpulan sebagai berikut:

1. Berdasarkan hasil uji regresi linear berganda nilai koefisien regresi stres kerja terhadap kepuasan kerja - 0,293 yang berarti apabila stres kerja berkurang maka kepuasan kerja akan bertambah dan dilihat juga hasil nilai thitung variabel stres kerja berpengaruh negatif dan signifikan terhadap kepuasan kerja pada karyawan Bank Mandiri Cabang Padang karena memiliki nilai thitung untuk variabel stres kerja sebesar 2,242 dengan nilai signifikansi 0,028 . Artinya tidak ada hubungan antara stres kerja terhadap kepuasan kerja.
2. Berdasarkan hasil uji regresi linear berganda nilai koefisien regresi motivasi kerja terhadap kepuasan kerja 1,129 yang berarti apabila motivasi kerja bertambah maka kepuasan kerja akan bertambah dan dilihat juga hasil nilai thitung variabel motivasi kerja berpengaruh positif dan signifikan terhadap kepuasan kerja pada karyawan Bank Mandiri Cabang Padang karena memiliki nilai thitung untuk variabel motivasi kerja sebesar 8,079 dengan nilai signifikansi 0,000 . Artinya adanya pengaruh antara motivasi kerja terhadap kepuasan kerja.

\section{Saran}

Berdasarkan kepada kesimpulan penelitian yang telah dilakukan maka diajukan beberapa saran yang dapat memberikan manfaat positif antaralain sebagai berikut:

1. Diharapkan kepada peneliti selanjutnya untuk dapat menggunakan penelitian ini sebagai referensi yang nantinya akan memberikan perbandingan dalam melakukan penelitian pada bidang yang sama dimasa yang akan datang.

2. Bagi penelitia agar dapat mengkaji lebih dalam wawasan dan pendalaman pengetahuan dalam manajemen sumber daya manusia khususnya yang berkaitan dengan Mengetahui Pengaruh Stres Kerja dan Motivasi Kerja terhadap Kepuasan Kerja Karyawan Bank Mandiri Syariah Cabang Padang.

3. Digunakan sebagai bahan yang bermanfaat untuk menambah pengetahuan tentang Mengetahui Pengaruh Pengaruh Stres Kerja dan Motivasi Kerja terhadap Kepuasan Kerja Karyawan Bank Mandiri Syariah Cabang Padang. 


\section{Daftar Pustaka}

As'ad, Moh, 1998. Psikologi Industri. Edisi kelima, liberty, Yogyakarta.

Furqon. 1997, Statistik Terapan Untuk Penelitian, Alpabeta, Bandung

Gouzaly, Saydam, Drs.200, Manajemen Sumber Daya Manusia , Gunung Agung, Jakarta.

Hasibuan, Melayu SP, 2001. Manajemen Sumber Daya Manusia, Edisi Revisi Bumi Aksara

Hasibuan, Melayu SP. 1984, Manajemen Dasar, Pengertian dan masalah, Bumi Aksara,Jakarta

Herzberg, Frederick. 1967, Work and The Nature of Man. The World Publishing CompanyCleveland And New York.

Keith, Davis, Jhon W. Newstrom, 1995. Perilaku Dalam Organisasi, Edisi Ketujuh,Erlangga, Jakarta.

Mangkunegara, AP. (2000). Manajemen Sumber Daya Manusia. Cetakan Pertama, Rosda,Bandung.

Manullang, M. 1982, Dasar-dasar Manajemen, Ghalia Indonesia, Jakarta
Marlius, D. (2018). Loyalitas Nasabah Bank Nagari Syariah Cabang Bukittinggi Dilihat Dari Kualitas Pelayanan. Jurnal Pundi. Volume 1. No. 3. Hal.1222.

https://doi.org/10.31575/jp.v1i3. 60

Pareek, Stephens. 1984, Perilaku Organisasi, PT. Pustaka Binaman Pressindo, Jakarta.

Robbins, Stephans. 1994. Organization Theory, Structure, Design and Application, Alih Bahasa Yusuf Udara, Arean, Jakarta.

Robbins, Stephans. 1996, Organization Bahaviour, Seventh Edition, A Simon \& SchusterCompany, Englewood Cliffs, New Jersey 07632.

Sarwoto Drs. 1979, Dasar-dasar Organisasi Management, Ghalia Indonesia, Jakarta.

Siagian, Sondang. 1983. Organisasi, Kepemimpinan dan Perilaku Adminsitrasi, PT.Gunung Agung, Jakatra

Singgih, Santoso. 2000. Mengolah Data Statistik Secara Profesional, Gramedia, Jakatra. 